(C) 1984. The Genetical Society of Great Britain

\title{
DOMINANCE RELATIONS AMONG THE MELANIC FORMS OF BISTON BETULARIUS AND ODONTOPERA BIDENTATA (LEPIDOPTERA, GEOMETRIDAE)
}

\author{
KAURI MIKKOLA \\ Zoological Museum, University of Helsinki, Helsinki, Finland
}

Received 4.ii.83

\section{SUMMARY}

\begin{abstract}
The black or dark coloration of Lepidoptera showing industrial melanism is regularly inherited as a unifactorially determined, fully dominant character. It has been suggested that non-linked modifiers in the genome are responsible for the dominance. To test this, melanic moths from the Liverpool area of Biston betularius (L.) (f. carbonaria) and of Odontopera (= Gonodontis) bidentata $(\mathrm{Cl}$.) (f. nigra) were crossed for five generations with typicals from Finland where no or few specimens of these melanic forms had been observed. The dominance could not be broken as the heterozygous and homozygous moths composed a relatively homogenous group. It is concluded that the dominance of these forms might be determined by the gene itself or modifiers linked to it. A less extreme melanic form of $O$. bidentata, named f. seminigra n.f., is probably an allelomorph with f. nigra, and also fully dominant over the typical form. Occurrence of the melanic forms of both species in northern Europe is reviewed.
\end{abstract}

\section{INTRODUCTION}

Half a century ago Fisher, Wright and Haldane presented their hypotheses about the nature of dominance. According to Fisher (1928), there are non-linked modifiers in the genome which cause the dominance. Wright (1934) and Haldane (1939) thought that the gene in its mutant form is alone responsible for the dominance.

Some workers on the so-called industrial melanism of Lepidoptera, e.g., Sheppard and Ford (1966) and Kettlewell (1973) have supported Fisher's hypothesis but for instance Crosby (1963) presented strong criticism against the modifier idea. Charlesworth and Charlesworth (1975), working on butterfly mimicry, calculated that effective change in modifier frequency could only come about if the modifiers happen to be closely linked to the mimicry locus.

Kettlewell (1973) showed that the black morph f. carbonaria of Biston betularius (L.) lost its dominance over the typical morph when crossed for three generations to Canadian Biston cognatarius (Guen.). The dominance was built up again when the intermediate forms were crossed with typical forms of British B. betularius. This was interpreted by Kettlewell as indicating that the British populations had evolved dominance modifiers while the Canadian one had not.

Because the carbonaria morph of $B$. betularius had never been observed in nature in Finland, and melanics of Odontopera bidentata $(\mathrm{Cl}$.) only recently, I decided to investigate if the dominance of the melanic forms of British origin could be broken when the genes were transferred to the Finnish genomes. In the latter species, in addition to f. nigra, a less extreme 
form has been observed in Finland, and as no available name has been found for it, it is described as a new form below. The genetic relation of this form to f. typica and to f. nigra was investigated

\section{OCCURRENCE OF THE MELANIC FORMS OF BISTON BETULARIUS AND ODONTOPERA BIDENTATA IN NORTHERN EUROPE}

The form carbonaria of Biston betularius was already present in the year 1900 at the southern coast of the Baltic Sea (Ule, 1925, Cleve, 1970, cf. fig. 1). The oldest Danish specimen dates from the year 1915 (Hoffmeyer, 1966) but the frequencies are still relatively low in Denmark and southernmost Sweden, usually under 5 per cent (Douwes et al., 1976). From W. Norway, the oldest specimen probably dates from the year 1934 when N.

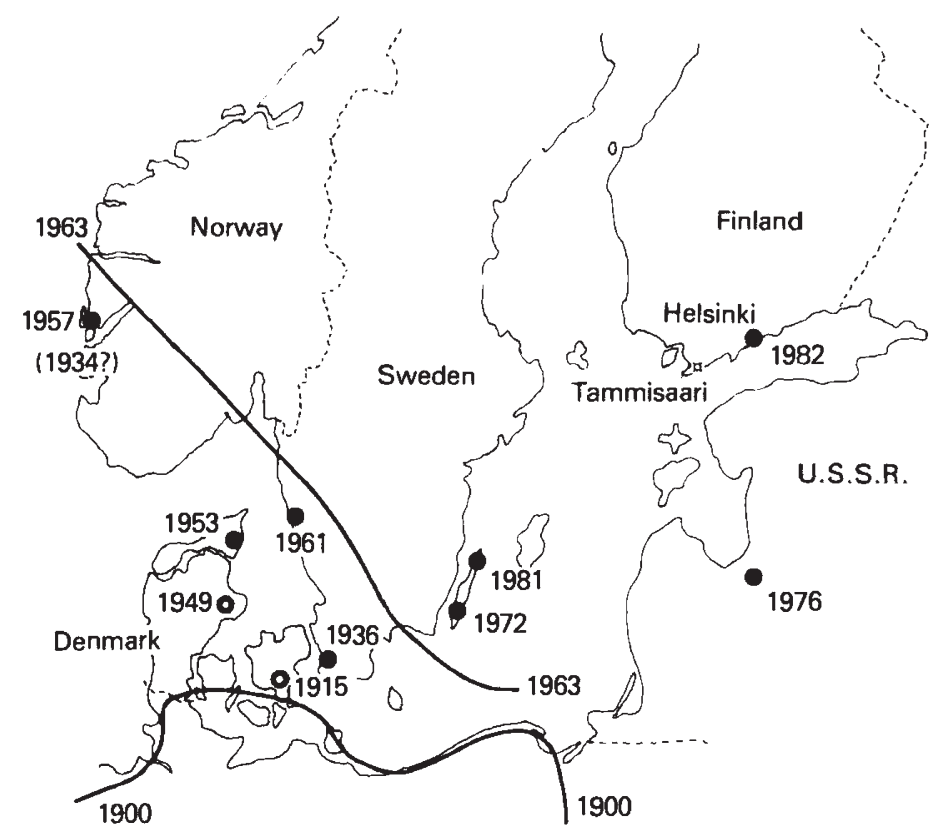

FIG. 1. Dispersal in northern Europe of Biston betularius f. carbonaria or, possibly, f. insularia indistinguishable from f. carbonaria. The limit of the year 1900 is from Cleve (1970); otherwise see Douwes et al. (1976) and text. Tammisaari is the locality where the crosses were made. Open circles: exact localities unknown.

Knaben began his crossing work (A. Fjeldså and T. Andersen, in litt.). The oldest well documented moth of this form is from the year 1957 and the highest frequency observed was under 10 per cent (Andersen and Bengtsson, 1980). The form is not known from the Oslo area (Andersen, in litt.). From Sweden the first find of $\mathrm{f}$. carbonaria is from the year 1936 from Scania (P. Douwes, in litt.) and the northernmost ones from the Gothenburg area where local frequencies may be close to 20 per cent (Douwes et al., 1976) and from the northern tip of Öland (B. A. Bengtsson, in litt.). No finds are known from the Stockholm area (L. Imby, in litt.). 

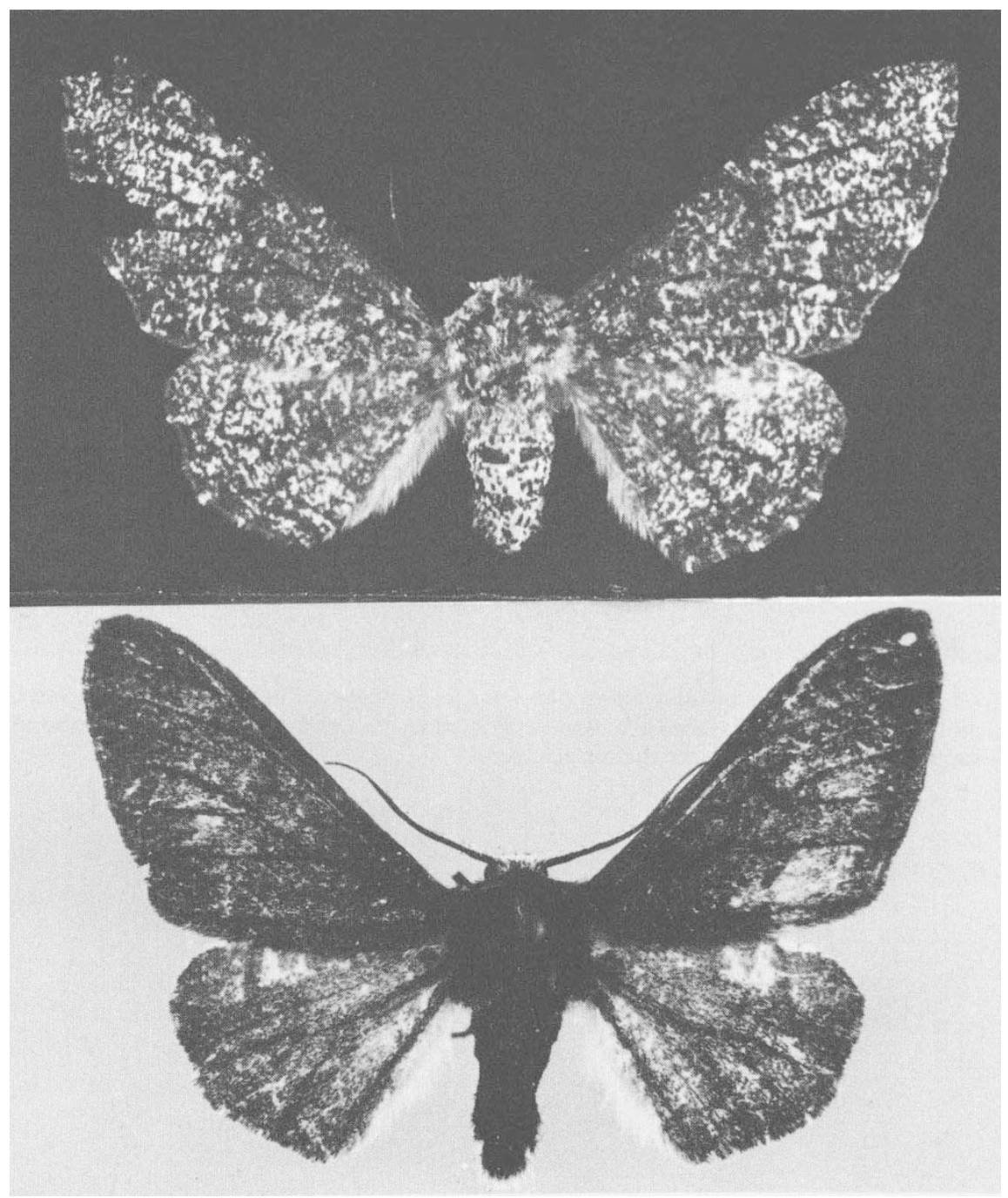

FIG. 2. Top: The darkest Biston betularius from Finland until the year 1974 when the crosses reported were begun, a female f. insularia from EH: Tampere 1969. Bottom: The first f. carbonaria (or f. insularia indistinguishable from f. carbonaria) from Finland, a male from Helsinki 1982. 


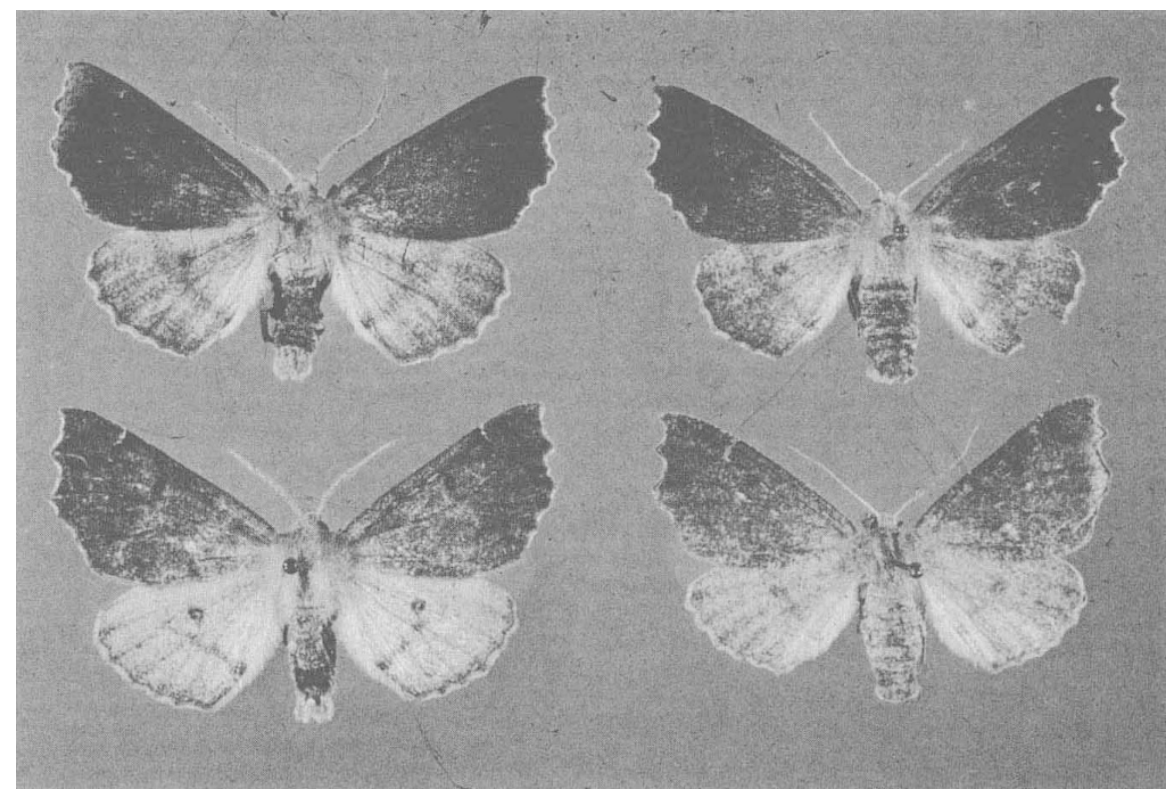

FIG. 3. Two chosen pairs of Odontopera bidentata from a cross of heterozygous f. seminigra moths, the darkest ones (top) are supposedly homozygous and the lightest ones (bottom) supposedly heterozygous for the melanic gene. 
Unlike in the British Isles, the frequencies of the $\mathrm{f}$. insularia may be as high as 62 to 78 per cent in Denmark and S. Sweden (Douwes et al., 1976). On the other hand random samples collected in Finland show that even in the centre of Helsinki, only slight darkening of the population has taken place (Douwes et al., 1976). The darkest B. betularius males from Finland, as measured on the scale of Douwes et al. $(1973,1976)$, did not exceed class 5 (cf. fig 2; values 4 to 7 represent f. insularia) until a class 7 male was found in Helsinki, Laajasalo in the year 1974. This moth has a weak dispersion of white scales on the wings and has therefore been held to be a f. insularia by several specialists (the moth is figured in Mikkola, 1976). However, two more melanics from the nearby Helsinki, Vallisaari from the year 1982 could not be distinguished from reared f. carbonaria, cf. figs. 1 and 2 . Though the f. insularia is not always distinguishable from $\mathrm{f}$. carbonaria (Clarke, 1979) moths as dark as the present ones have certainly been held as f. carbonaria in all studies outside Great Britain. Until other facts are available, it is therefore necessary to take these moths as $\mathrm{f}$. carbonaria.

In the Baltic countries, U.S.S.R., the northernmost find of $f$. carbonaria was made in 1976 near Riga in Latvia (Sulcs, 1978), $350 \mathrm{~km}$ south of Finland. The form has not been observed in the Leningrad area (V. Mironov and I. L. Sukhareva, oral comm.), in spite of roughly 6 million inhabitants and presumably heavy pollution.

Thus, the occurrence of the f. carbonaria was for long time limited to the southwesternmost parts of Fennoscandia (fig. 1). New finds may indicate dispersal of the form. However, the distance between, e.g., Riga and Helsinki is so big, that the possibility of independent mutation must be taken into account, besides that of long-range flights.

Nearly ten infrasubspecific names have been given to the forms of $O$. bidentata. In addition to f. nigra Prout, three of them refer to dark or melanic morphs: f. fusca Lempke, dark typical, cf. Bishop and Harper (1970) f. hafneri Wagner, the transverse lines sharply whitish, and f. bowateri Cockayne, the forewing median area relatively light, terminal area on the underside light. As none of these refers to the form found in Finland and used in crosses of the present study, the form is named as f. seminigra n.f. This form is darker than f. fusca but lighter than f. nigra (fig. 3). The forewing is unicoloured yellow-brownish blackish, slightly mottled, weakly marked, usually only the middle spot being well visible, the hindwing and body are clearly lighter, the undersides of the wings are typically mottled with blackish stripes but varying from nearly unicoloured light to nearly unicoloured dark (in f. nigra always unicoloured dark). In addition to the Finnish moths, I have seen this form in the Rothschild-Cockayne-Kettlewell Collection of the British Museum of Natural History under the name $f$. hafneri.

Few details are available about the history of melanism of $O$. bidentata in northern Europe. The f. nigra is said to have occurred in Denmark since 1950 (Hoffmeyer, 1966). This note probably does not distinguish between f. nigra and f. seminigra, though all 5 Danish specimens inspected represented f. nigra. Melanic specimens are known from 6 (SJ, NEJ, LFM, SZ, NEZ, B) out of 11 provinces of Denmark, from NEJ and B already from the year 1956. The total of melanics from Denmark probably does not much exceed 10 specimens (O. Karsholt, in litt.). From Norway and Sweden, only one melanic specimen from each is known to me: Østfold, Jelöy 1955 
(sec. M. Opheim) and Öland, Möckelmossen 1977 (L. Imby), respectively, both of them probably of $f$. nigra.

In Finland, a clear increase in the melanism of $O$. bidentata has happened during the 1960s and 1970 s, with the f. seminigra ahead (fig. 4). The earliest find of this form is from the year 1954 from Turku, S.W. Finland (noted as f. nigra by Hoffmeyer, 1966). The first f. nigra is from the year 1966 from a southeastern inland locality, Mäntyharju. Nowadays, several specimens of both forms are collected yearly. The increase in occurrence is probably greater than seen in fig. 4 since the collectors have probably become more familiar with the melanics during the last ten years and do not report them as actively as earlier.

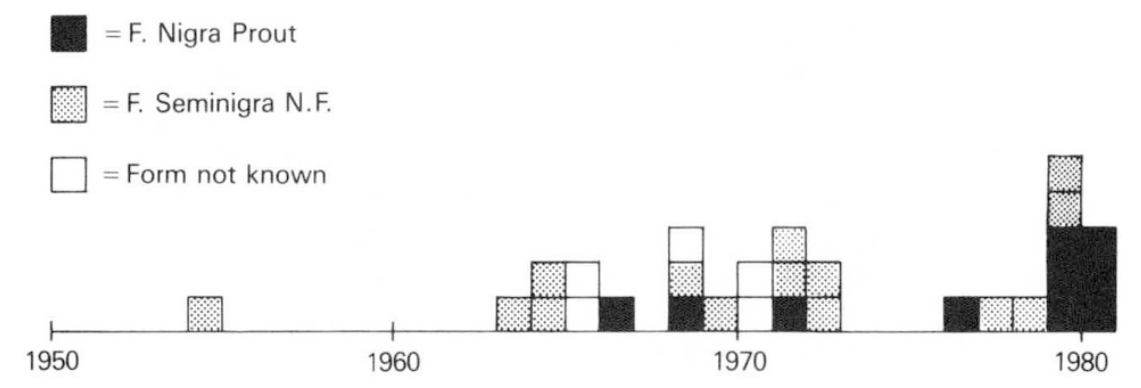

FIG. 4. All known finds of melanic Odontopera bidentata from Finland up to the year 1980 , divided into f. nigra, f. seminigra and nigra/seminigra. The total is 29 observations.

At Tammisaari, south-west Finland (fig. 1) where I have collected night-flying moths continuously in the summers of the years 1966-1982, the first two examples of $O$. bidentata f. seminigra were observed in 1972 (total 92 moths), the third, the P male of the crosses, in 1977 and the fourth in 1982 (one of 62 moths).

\section{THE CROSSES}

A stock of $B$. betularius f. carbonaria from Meols, Wirral Peninsula, was obtained from Sir Cyril Clarke and the late Prof. P. M. Sheppard and a stock of $O$. bidentata f. nigra from Liverpool from the late Dr J. A. Bishop. From the year 1974 on, melanic females of both species were yearly crossed with typical males of Finnish origin. The families were reared in terylene net sleeves placed over young trees of Betula or Fraxinus. Because the segregation ratios were not investigated, mortality which was at times relatively high was neglected. Several parallel lines were maintained but 'as no differences between them were observed' they are treated together. Crosses were continued to the $F_{5}$ generation in 1979. In 1978, melanic $x$ melanic crosses were made with $\mathrm{F}_{4}$ generation in order to investigate actual differences between the homozygote and heterozygote moths (cf. table 1).

In 1977 , a live male of $O$. bidentata f. seminigra was caught at Tammisaari and crossed with a typical female of British-Finnish origin. In 1978, both in the seminigra line and in a nigra line melanic $\times$ melanic crosses were made. In 1979, the darkest moths of the offspring of both lines were chosen to represent homozygotes and subsequently crossed ( $P$ generation) in order 
TABLE 1

Crosses made with Biston betularius. $C=$ the carbonaria gene, $+=$ the wild type gene

\begin{tabular}{llll}
\hline & & & $\begin{array}{c}\text { Proportion of } \\
\text { English genes }\end{array}$ \\
\hline P & 1974 & $++\times C C$ & \\
F1 & 1975 & $++\times C+$ & $(50 \%)$ \\
F2 & 1976 & $++\times C+$ & $(25 \%)$ \\
F3 & 1977 & $++\times C+$ & $(12.5 \%)$ \\
F4 & 1978 & $++\times C+$ & $(\sim 6 \%)$ \\
F5 & 1979 & $C+$ & $(\sim 3 \%)$ \\
F4 $\times$ F4 & 1978 & $\mathrm{C}+\times \mathrm{C}^{+}$ & $(\sim 6 \%)$ \\
& 1979 & $\mathrm{CC}, \mathrm{C}+,++$ & $(\sim 6 \%)$ \\
\hline
\end{tabular}

to determine whether the genes are situated at the same locus. $F_{1}$ moths having both nigra and seminigra genes were crossed in 1980 in 7 broods. These produced $120 \mathrm{~F}_{2}$ moths in 1981 .

\section{THE DOMINANCE OF F. CARBONARIA AND F. NIGRA}

In both species the proportion of British genes was halved in each year, i.e., it was 50 per cent in the $F_{1}$ generation in 1975 and 3.1 per cent in the $F_{5}$ generation in 1979 (Table 1). In neither species was the dominance broken, since no clear lightening had occurred by the $F_{s}$ generation. The only effects were, on average, in f. carbonaria, a slight increase of white scales on forewing and somewhat lighter hindwings in males, and in f. nigra perhaps slightly clearer brownish tint on forewing and somewhat lighter outer margin of the hindwing underside. But in both species, some individuals of the $F_{5}$ were as dark as those of the $P$ and $F_{1}$ generations.

The melanic $\times$ melanic crosses with moths of the $F_{4}$ generation $(6 \cdot 25$ per cent of British genes) gave also informative results. The offspring in 1979 , of course, had the same proportion of genes of British origin but the melanic genes occurred in single and in double doses, or were absent, in the expected ratio $2: 1: 1$. The melanics could not, however, be separated into two groups in either species. A lot of variation could be seen, but without any clear border between the homozygotes and heterozygotes. As the experiment with the nigra and seminigra forms of $O$. bidentata showed, the darkest melanics in that species probably were homozygotes and probably the lightest heterozygotes. Between these extremes there were, however, the majority of the moths, probably both homo- and heterozygotes.

\section{THE GENETICS OF THE F. SEMINIGRA}

The 1977 cross $\delta$ f. seminigra $\times \uparrow$ f. typica produced equal numbers of each form in the $F_{1}$ generation: $f$. seminigra 29 moths and f. typica 29 Hmoths (mortality was negligible). The 1978 cross between seminigra moths produced f. seminigra and f. typica roughly in a 3: 1 ratio. Thus, the seminigra colouration is fully dominant over the typica colouration and is unifactorially determined (cf. fig. 3). As expected, the wild-caught $\delta$ was heterozygous for the seminigra gene. The 1979 cross f. nigra $\times$ f. seminigra produced invariably f. nigra, so this form is fully dominant (epistatic) over f. seminigra. 
As the crosses of such nigras did not produce any typicals, it seems that in the $\mathrm{P}$ cross the moths were homozygous, i.e., $N N \times n n$, and $F_{1}$ cross would correspondingly have been $N n \times N n$. This cross produced invariably melanics, f. nigra or f. seminigra, altogether 120 moths. If one of the $P$ moths had been heterozygous for the melanic gene, some of the 7 broods should have produced the typical form in the ratio $1: 3$. The probability that no typicals would appear in this case is as high as 0.134 , however, and, consequently, this possibility cannot be excluded. Differential mortality of the morphs, by chance or otherwise, could also cause that the typicals remain unnoticed.

If the genes for nigra and seminigra coloration were situated in different loci and unlinked, even in the maximum case typical moths should appear in frequency $1 / 16$. From this, the observed ratio, $0: 120$, differs highly significantly $(p<0.001)$. If there is linkage the chance becomes $(1 / 8) \times$ COV and using $\chi^{2}$ test the data are compatible at the $p<0.05$ level with the assumption of two loci up to 24 map units apart. Thus, the data indicate that the forms are allelomorphs but for definite proof more information is needed.

\section{Discussion}

Industrial melanic forms of Lepidoptera are usually fully dominant over the typical forms (Kettlewell, 1973). The forms nigra and seminigra of Odontopera bidentata is the third known case where two melanic forms of a single species, an extreme dark and an intermediate one, have been shown to be allelomorphs. In Phigalia and Odontopera the intermediate forms are fully dominant over the typical form but in Biston betularius the dominance is incomplete (Lees and Creed, 1977). In the Noctuid moth Oligia strigilis (L.) crossing results clearly pointed to semi-dominance and this might be the rule in the industrial melanism of Oligia moths (Mikkola, 1980). Also in Polia nebulosa (Hfn.) the heterozygotes and homozygotes are readily distinguishable and a similar situation might occur in some North American Geometrids (Kettlewell, 1973).

Recessive industrial melanism is rare, but occurs in Lycia hirtaria (Cl.), and Lasiocampa quercus (L.) (Kettlewell, 1973), and in Pachycnemia hippocastanaria $(\mathrm{Hb}$.) in which low temperatures may produce similar forms as the recessive one (Majerus, 1981).

Kettlewell (1973) pointed out that in Biston betularius modern f. carbonaria individuals may be darker than those present during the early stages of industrialisation. With that exception, all the examples quoted are constant in phenotypic expression.

The island-like melanism of Oligia strigilis in Finland shows that, in this case, the melanism has arisen several times, independently of each other (Mikkola, 1980). Hardly any signs of increase of dominance have been observed, so that in this case, too there is no evidence of change of dominance.

The late Dr H. B. D. Kettlewell and Dr D. F. Owen (oral communication) proposed that the British $\mathrm{f}$. carbonaria gene should be transferred to a population of Biston betularius where f. carbonaria does not occur in order to study the gene expression. This has now been done with the Finnish population but the dominance could not be broken. Either the Finnish population has similar (non-linked) modifiers to the British one or there 
are no modifiers. Because the Finnish population would be expected to lack appropriate modifiers, the result is against the modifier hypothesis.

A similar result with Odontopera bidentata f. nigra is not as informative because single specimens of this form had been observed in Finland already before the experiment. That the two genes in the same locus, for $\mathrm{f}$. nigra and for f. seminigra, are both dominant over f. typica points to the gene hypothesis. In fact, I first believed that $\mathrm{f}$. seminigra is a Finnish heterozygote of $f$. nigra. But because the homozygotes do not approach f. nigra but clearly belong to f. seminigra, different genes are involved. Why should the modifiers affect the expression of one gene but not of the other? The same question applies to the results of Lees (1974) with Phigalia and partly to those of Lees and Creed (1976) with $B$. betularius. In all cases the observations are more easily explained by differences in the gene activities themselves.

Why then did the dominance break down in crosses between Biston betularius f. carbonaria and B. cognatarius f. typica (Kettlewell, 1973)? In fact, the latter taxon should be called $B$. betularius cognatarius, a subspecies of the Peppered Moth (e.g., Viidalepp, 1979). It seems to me that the $B$. betularius cognatarius population of North America is on the way to speciation and the results of Kettlewell should be interpreted as differentiation of the genomes of these taxa. Indicative of such a situation is that some upset of the sex valency took place among the offspring (Kettlewell, 1973, p. 316). Now a similar experiment with a taxon which is certainly conspecific has produced results contradictory to the cognatarius ones but quite similar to those of Kettlewell with a Cornish stock. It is to be expected that if the melanic form swettaria which occurs in $B$. betularius cognatarius further south in the United States be crossed into the Canadian population the dominance will not be broken because the gene shows its proper function in that genome. Thus, I think that the present result with $B$. betularius points to the other possibility Kettlewell suggested, substitution of previous genes by more effective ones (the Haldane hypothesis). The other alternative is function of linked modifiers (cf. Charlesworth and Charlesworth, 1975), i.e. of a supergene.

Genetic background certainly affects the dominance relations of the mimetic forms of e.g., Papilio dardanus (Brown) (see Clarke and Sheppard, 1960), and the selection experiments with Abraxas grossulariata (L.), Noctua comes $\mathrm{Hb}$. and Callimorpha dominula (L.) (Ford, 1940) point to the same direction. The Canadian-British cross with $B$. betularius (Kettlewell, 1973) also shows that genetic background may affect dominance.

In the light of the earlier and the present results it seems unnecessary to try to explain dominance in a single way: it seems that several mechanisms may be involved. In industrial melanism of Lepidoptera, evolution seems to have led to the possibility that the mutations are directly dominant, irrespective of the genetic background in which they work. If separate dominance modifiers are involved they must be tightly linked with the melanic gene.

Acknowledgments. The melanic stocks were delivered by Sir Cyril Clarke, the late Professor P. M. Sheppard and the late Dr J. A. Bishop. Notes on the occurrence of the melanic forms were given by $\mathrm{Mr}$ O. Karsholt (Denmark), Mr T. Andersen, Mr M. Opheim (Norway), Mr B. A. Bengtsson, Dr P. Douwes, Mr I. Imby, Mr I. Svensson (Sweden), Mr V. Mironov, 
Mrs I. L. Sukhareva (U.S.S.R.) and many Finnish lepidopterists. Mr. P. Vakkari assisted in the statistical treatment. Dr L. M. Cook read the manuscript critically. I am grateful to all these persons. The work was made under the tenure of grants from the National Research Council for Sciences, the University of Helsinki and the Maj and Tor Nessling Foundation.

\section{REFERENCES}

ANDERSEN, T. AND Bengtson, S. A. 1980. Melanism in the Peppered Moth Biston betularia (L.) in western Norway (Lepidoptera: Geometridae). Ent. scand., 11, 245-248.

BISHOP, J. A. AND HARPER, P. S. 1970. Melanism in the moth Gonodontis bidentata: a cline within the Merseyside conurbation. Heredity, 25, 449-456.

CHARLESWORTH, D. AND CHARLESWORTH, B. 1975. Theoretical genetics of Batesian mimicry, J. theor. Biol., 55, 283-324.

CLARKE, C. A. 1979. Biston betularia, obligate f. insularia indistinguishable from f. carbonaria (Geometridae). J. Lepidopterists' Soc., 33, 60-64.

ClARKe, C. A. AND ShEPPARD, P. M. 1960. The evolution of mimicry in the butterfly Papilio dardanus. Heredity, 14, 163-173.

CLEVE, K. 1970. Die Erforschung der Ursachen für das Auftreten melanistischer Schmetterlingsformen im Laufe der letzten hundert Jahre. Z. angew. Entomol., 65, 371-387.

CROSBY, J. L. 1963. The evolution and nature of dominance. J. theoret. Biol., 5, 35-51.

DOUWES, P., MIKKOLA, K., PETERSEN, B. AND VESTERGREN, A. 1976. Melanism in Biston betularius from north-west Europe (Lipidoptera: Geometridae). Ent. scand., 7, 261-266.

DOUWES, P., PETERSEN, B. AND VESTERGREN, A. 1973. Melanism hos Biston betularius L. i Danmark och södra Sveridge. Entomologen, 2, 15-20.

FISHER, R. A. 1928. The possible modification of the response of the wild type to recurrent mutations. Amer. Nat., 62, 115-126.

FORD, E. B. 1940. Genetic research in Lepidoptera. Ann. Eugen., London, 10, 227-252.

HALDANE, J. B. S. 1939. The theory of the evolution of dominance. J. Genet., 37, 365-374. HOFFMEYER, S. 1966. De danske målere. 2den udgave. Universitets-forlaget i Aarhus, Århus. KETTLEWElL, H. B. D. 1973. The evolution of melanism. Clarendon Press, Oxford.

LEES, D. R. AND CREED, E. R. 1977. The genetics of the insularia forms of the Peppered moth, Biston betularia. Heredity, 39, 67-73.

MAJERUS, M. E. N. 1981. The inheritance and maintenance of the melanic form nigrescens of Pachycnemia hippocastanaria (Lepidoptera: Ennominae). Ecol. Entom., 6, 417-422.

MIKKOLA, K. 1976. Perhosten melanismi kertoo ilman saastumisesta. (Melanistic moths as indicators of air pollution.) Suomen Luoto, 35, 89-93.

MIKKOLA, K. 1980. Origin and genetics of industrial melanism of Oligia strigilis (L.) in Finland (Lepidoptera: Noctuidae). Ent. scand., 11, 1-8.

SHEPPARD, P. M. AND FORD, E. B. 1966. Natural selection and the evolution of dominance. Heredity, 21, 139-147.

SulCS, A. AND ŠULCS, I. 1978. Neue und wenig bekannte Arten der Lepidopterenfauna Lettlands. 7. Mitteilung. Notulae Entomol., 58, 141-150.

ULE, C. H. 1925. Über Auftreten und Verbreitung von Amphidasis betularia L., f. carbonaria Jord. auf dem Kontinent. Internat. Entomol. Z., 18, 257-263.

VIIDALEPP, J. 1979. K faune cheshuekrylykh Tuvynckoy ASSR. (On the fauna of the Lepidoptera of Tuva ASSR.) IV. Geometridae. Tartu Riikliku Ülikooli Toimetides, 483, 79-133.

WRIGHT, S. 1934. Physiological and evolutionary theories of dominance. Amer. Nat., 68, 25-53. 